\title{
THE MICROBIAL ECOLOGY OF THE LARGE BOWEL OF BREAST- FED AND FORMULA-FED INFANTS DURING THE FIRST YEAR OF LIFE
}

\author{
P. L. Stark AND A. LeE \\ School of Microbiology, University of New South Wales, \\ PO Box 1, Kensington, N.S.W. 2033, Australia
}

\begin{abstract}
SUMMARY. The succession of bacterial populations in the large bowel of seven breast-fed and seven formula-fed infants was examined during the first year of life. The composition of the intestinal microflora varied according to the infant's diet. During the first week of life breast-fed and formula-fed infants were colonised by enterobacteria and enterococci followed by bifidobacteria, Bacteroides spp., clostridia and anaerobic streptococci. From week 4 until solid foods were given, breast-fed babies had a simple flora consisting of bifidobacteria and relatively few enterobacteria and enterococci. Formula-fed babies during the corresponding period were more often colonised by other anaerobes in addition to bifidobacteria and had higher counts of facultatively anaerobic bacteria. The introduction of solid food to the breast-fed infants caused a major disturbance in the microbial ecology of the large bowel as counts of enterobacteria and enterococci rose sharply and colonisation by Bacteroides spp., clostridia and anaerobic streptococci occurred. This was not observed when formula-fed infants began to take solids; instead, counts of facultative anaerobes remained high while colonisation by anaerobes other than bifidobacteria continued. At 12 months, the anaerobic bacterial populations of the large bowel of breast-fed and formula-fed infants were beginning to resemble those of adults in number and composition and there was a corresponding decrease in the number of facultative anaerobes. These changes are discussed in relation to changes in susceptibility to gastro-intestinal infection.
\end{abstract}

\section{INTRODUCTION}

The autochthonous bacteria inhabiting the gastro-intestinal tract of man influence the health of their host in various ways. For example, they contribute to resistance against colonisation by enteric pathogens (van der Waaij, 1979) and are thought to be involved in the aetiology of cancer of the large bowel (Hill, 1974). The normal balance between competing organisms is established during infancy and might be expected to be attained by successive stages, following a definite time sequence and under the influence of dietary change as has already been demonstrated in rodents (Lee et al., 1971). 
Mata and Urrutia (1971) reported a prospective study of the succession of bacteria in the large bowel of breast-fed infants. The infants studied, however, lived in a rural area of Guatemala where standards of hygiene and nutrition are poor and breast feeding continues for much longer periods than is practised in industrialised societies. Other recent studies have been short term or have grouped together infants of widely differing ages and sometimes also differing feeding practices.

In the present investigation we have examined the succession of bacteria in the large bowel of healthy breast-fed and bottle-fed infants during the first year of life.

\section{MATERIALS AND METHODS}

Selection of subjects. Fourteen babies born at the Women's Hospital, Crown Street, Sydney were selected for the prospective study. They lived in Sydney suburban homes where high standards of nutrition and hygiene were practised. None of the children suffered from gastrointestinal or any major illness or received antibiotic therapy during the course of the survey.

Seven babies were breast fed for periods ranging from 3 to 10 months. Seven were artificially fed from birth although three of these also received limited amounts of breast milk during the first 1-2 weeks of life. Solid foods, usually in the form of cereals in cow's milk, were first given between the 10th and 28th weeks (average 17 weeks).

In addition, single specimens of faeces were collected from 20 healthy 9-month-old infants. Ten had been formula fed since birth and 10 were still receiving breast milk in addition to some solid foods. The infants lived in Sydney homes and were contacted during routine visits to Baby Health Clinics. Single specimens of faeces were also collected from 20 adults from among the staff and postgraduate students at the University of New South Wales.

Collection of specimens. Faeces $(c .0 .5 \mathrm{~g})$ were collected with sterile wooden spatulas and transported in $5.5-\mathrm{ml} \mathrm{screw-capped} \mathrm{glass} \mathrm{bottles} \mathrm{containing} 4.5 \mathrm{ml}$ of salts solution (Holdeman and Moore, 1975), with glycerol $10 \%$, cysteine $\mathrm{HCl} 0.5 \mathrm{~g} / \mathrm{L}$, and resazurin $1 \mathrm{mg} / \mathrm{L}$, overlaid by a thin layer of paraffin oil. The transport devices were pre-reduced in an anaerobic chamber and discarded if at any time the resazurin turned pink. All samples were frozen at $-60^{\circ} \mathrm{C}$ on the day of collection and held at that temperature until cultured (Crowther, 1971).

Four or five samples were collected from each baby in the prospective study during the first week of life, and single samples at 4 weeks and at approximately 6-weekly intervals thereafter.

Culture and identification of bacteria. A flexible vinyl anaerobic chamber, containing a gas mixture of $90 \% \mathrm{CO}_{2}$ and $10 \% \mathrm{H}_{2}$ circulated over a palladium catalyst, was used for the culture of anaerobes. Frozen samples were thawed inside the chamber and serial tenfold dilutions made in $4.5 \mathrm{ml}$ of pre-reduced brain-heart infusion (BHI).

Culture media and incubation conditions are summarised in table I. Plates for anaerobic incubation contained cysteine $\mathrm{HCl} 0.5 \mathrm{~g} / \mathrm{L}$ and were stored inside the chamber for $24 \mathrm{~h}$ before inoculation with $0 \cdot 1-\mathrm{ml}$ quantities of the faecal dilutions. Willis and Hobbs (1959) agar was inoculated with dilutions which had been heat shocked at $75^{\circ} \mathrm{C}$ for $12 \mathrm{~min}$.

After incubation, 10 colonies were picked at random from BHI-agar plates and subcultured for aerobic and anaerobic incubation. Isolates confirmed to be obligate anaerobes were inoculated into BHI broth containing yeast extract $0.5 \%$, glucose $0.4 \%$, cellobiose $0 \cdot 1 \%$, maltose $0.1 \%$ and starch $0.1 \%$ for gas-liquid chromatography. In addition, colonies of each distinctive morphology were picked from vancomycin-kanamycin, tomato-juice and Willis and Hobbs agar plates and subcultured as described previously. With the exception of heat shocking, all procedures described above were done inside the anaerobic chamber.

Lactobacilli were counted by the same technique except that incubation was in a candle jar. Because MRS medium (Oxoid CM361) also supports the growth of gram-positive cocci and some gram-negative rods, colonies from these plates were gram stained before subculture into broths.

Enterobacteria and enterococci were counted by a modified Miles and Misra technique (Miles, Misra and Irwin, 1938).

Bacterial counts were expressed as colony-forming units (cfu)/g of wet faeces. 
Identification of anaerobic isolates was based on the gram-stain morphology and the gas-chromatographic identification of volatile fatty acids and nonvolatile acids produced as end products of carbohydrate fermentation. Sugar-fermentation reactions and spore tests were sometimes required for differentiation between members of the genera Clostridium, Bifidobacterium and Eubacterium (Holdeman and Moore, 1975).

\section{RESULTS}

Preliminary evaluation of results showed that bacterial populations were influenced by the diet rather than the age of the babies. For this reason data were analysed in terms of changing feeding regimens as shown in table II. When more than one sample was collected during a particular stage of feeding, the culture results of only one specimen are given because it was found that bacterial populations for each baby did not change appreciably within the feeding modes described.

\section{Obligate anaerobes}

Bifidobacteria. The culture results for the bifidobacteria are shown in table III. During the first week of life, six of the seven breast-fed babies were colonised by bifidobacteria. By week 4 all the breast-fed babies were colonised and counts remained in the range $10^{9}-10^{11} \mathrm{cfu} / \mathrm{g}$ of faeces throughout the first year.

Colonisation of two of the bottle-fed group was delayed, bifidobacteria being first isolated from baby no. 9 at week 27 and baby no. 12 at week 30 . When colonisation had occurred, counts in the bottle-fed infants were in the same range as those in the breast-fed group.

TABLE I

Culture media and conditions of incubation

\begin{tabular}{|c|c|c|c|c|c|}
\hline \multirow{2}{*}{$\begin{array}{l}\text { Culture } \\
\text { medium }\end{array}$} & \multirow{2}{*}{$\begin{array}{l}\text { Dilutions } \\
\text { cultured } \\
\left(\log _{10}\right)\end{array}$} & \multicolumn{3}{|c|}{ Incubation } & \multirow[b]{2}{*}{ Bacteria } \\
\hline & & time & temp. & atmosphere & \\
\hline $\begin{array}{l}\text { Brain heart infusion } \\
\text { agar } *(\text { Holdeman and } \\
\text { Moore, 1972) }\end{array}$ & $6-9$ & 3 days & $37^{\circ} \mathrm{C}$ & Anaerobic & Total anaerobes \\
\hline $\begin{array}{l}\text { Vancomycin-kanamycin } \\
\text { agar *(Finegold } \text { et al., 1971) }\end{array}$ & $2-5 \dagger$ & 3 days & $37^{\circ} \mathrm{C}$ & Anaerobic & $\begin{array}{l}\text { Bacteroides spp. } \\
\text { Fusobacterium } \text { spp } \\
\text { Veillonella } \text { spp. }\end{array}$ \\
\hline $\begin{array}{l}\text { Tomato-juice agar } \\
\text { with kanamycin } \\
\text { and nalidixic acid } \\
\text { (Finegold } \text { et al., 1971) }\end{array}$ & $2-5 \dagger$ & 3 days & $37^{\circ} \mathrm{C}$ & Anaerobic & Bifidobacteria \\
\hline $\begin{array}{l}\text { Willis' and Hobbs' agar } \\
\text { (Willis and Hobbs, 1959) }\end{array}$ & $2-4$ & 3 days & $37^{\circ} \mathrm{C}$ & Anaerobic & Clostridia \\
\hline MRS (Oxoid, CM361) & $2-5$ & 3 days & $37^{\circ} \mathrm{C}$ & $\mathrm{CO}_{2}$ & Lactobacilli \\
\hline $5 \%$ sheep-blood agar & $2-7$ & $\begin{array}{l}\text { over- } \\
\text { night }\end{array}$ & $37^{\circ} \mathrm{C}$ & Aerobic & Total aerobes \\
\hline MacConkey agar & $2-7$ & $\begin{array}{l}\text { over- } \\
\text { night }\end{array}$ & $37^{\circ} \mathrm{C}$ & Aerobic & $\begin{array}{l}\text { Enterobacteria } \\
\text { enterococci }\end{array}$ \\
\hline
\end{tabular}

* Supplemented with $10 \%$ horse blood, vitamin $\mathrm{K}$, haemin and yeast extract.

$\dagger$ Higher dilutions were cultured when the baby was known to be already colonised by the organisms being selected. 
TABLE II

Stages in the succession of bacterial populations in the infant large bowel

\begin{tabular}{|c|c|c|}
\hline \multicolumn{2}{|c|}{$\begin{array}{l}\text { Stage (and average age) } \\
\text { of babies that were }\end{array}$} & \multirow[t]{2}{*}{ Description } \\
\hline breast fed & formula fed & \\
\hline Week 1 & Week 1 & First bacterial inoculum \\
\hline Week 4 & Week 4 & $\begin{array}{l}\text { Early colonisation under the influence of } \\
\text { either breast milk or formula }\end{array}$ \\
\hline $\begin{array}{l}\text { Pre-weaning } \\
\text { (14 weeks) }\end{array}$ & $\begin{array}{l}\text { Pre-solids } \\
\text { (12 weeks) }\end{array}$ & $\begin{array}{l}\text { Bacterial flora which stabilises under the } \\
\text { influence of breast milk or formula }\end{array}$ \\
\hline $\begin{array}{l}\text { Early weaning } \\
\text { (20 weeks) }\end{array}$ & $\begin{array}{l}\text { After solids } \\
\text { ( } 23 \text { weeks })\end{array}$ & $\begin{array}{l}\text { Immediate effect of introducing solid } \\
\text { foods to the diet }\end{array}$ \\
\hline $\begin{array}{l}\text { Late weaning } \\
\text { ( } 37 \text { weeks) }\end{array}$ & $\begin{array}{l}9 \text { months } \\
\text { ( } 39 \text { weeks) }\end{array}$ & $\begin{array}{l}\text { Effect of a prolonged mixed diet of either } \\
\text { breast milk plus solids or formula plus solids }\end{array}$ \\
\hline 12 months & 12 months & $\begin{array}{l}\text { Bacterial flora of fully weaned breast-fed infant } \\
\text { compared with formula-fed infant of the same age }\end{array}$ \\
\hline
\end{tabular}

TABLE III

Colonisation of the infant large bowel by bifidobacteria

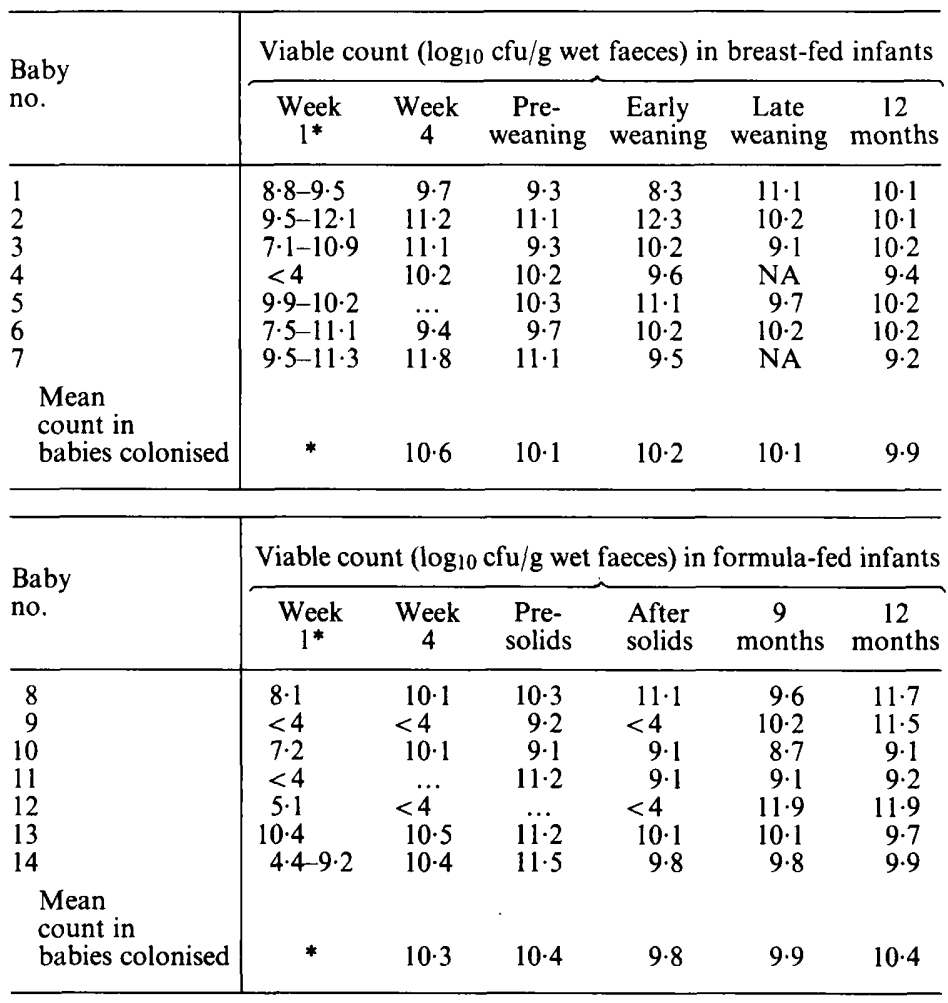

* Because counts fluctuated widely during week 1 , the range of values is given, and mean could not be calculated.

$\ldots=$ Specimen not obtained; NA = not applicable, babies weaned over a short period. 
TABLE IV

Colonisation of the infant large bowel by Bacteroides spp.

\begin{tabular}{|c|c|c|c|c|c|c|}
\hline \multirow[b]{2}{*}{$\begin{array}{l}\text { Baby } \\
\text { no. }\end{array}$} & \multicolumn{6}{|c|}{ Viable count ( $\log _{10} \mathrm{cfu} / \mathrm{g}$ wet faeces) in breast-fed infants } \\
\hline & $\begin{array}{c}\text { Week } \\
1^{*}\end{array}$ & $\begin{array}{c}\text { Week } \\
4\end{array}$ & $\begin{array}{c}\text { Pre- } \\
\text { weaning }\end{array}$ & $\begin{array}{c}\text { Early } \\
\text { weaning }\end{array}$ & $\begin{array}{c}\text { Late } \\
\text { weaning }\end{array}$ & $\begin{array}{c}12 \\
\text { months }\end{array}$ \\
\hline $\begin{array}{l}1 \\
2 \\
3 \\
4 \\
5 \\
6 \\
7 \\
7\end{array}$ & $\begin{array}{l}<3 \\
6 \cdot 3-11 \cdot 2 \\
<3 \\
10 \cdot 7-11 \cdot 2 \\
4 \cdot 2-10 \cdot 2 \\
7 \cdot 2 \\
<3\end{array}$ & $\begin{array}{l}<3 \\
<3 \\
<3 \\
<3 \\
\cdots \\
<3 \\
7 \cdot 2\end{array}$ & $\begin{array}{l}<3 \\
<3 \\
<3 \\
<3 \\
<3 \\
<3 \\
7 \cdot 1\end{array}$ & $\begin{array}{r}<3 \\
<3 \\
<3 \\
10 \cdot 1 \\
8 \cdot 2 \\
<3 \\
9 \cdot 7\end{array}$ & $\begin{array}{l}7 \cdot 1 \\
9 \cdot 6 \\
8 \cdot 1 \\
\text { NA } \\
9 \cdot 3 \\
7 \cdot 1 \\
\text { NA }\end{array}$ & $\begin{array}{r}10 \cdot 8 \\
11 \cdot 1 \\
10 \cdot 3 \\
9 \cdot 6 \\
9 \cdot 3 \\
8 \cdot 1 \\
10 \cdot 2\end{array}$ \\
\hline \multirow[t]{2}{*}{$\begin{array}{l}\text { Mean } \\
\text { count in } \\
\text { babies colonised }\end{array}$} & * & $\cdots$ & $\cdots$ & $9 \cdot 3$ & $8 \cdot 2$ & $9 \cdot 9$ \\
\hline & \multicolumn{6}{|c|}{ Viable count ( $\log _{10} \mathrm{cfu} / \mathrm{g}$ wet faeces) in formula-fed infants } \\
\hline $\begin{array}{l}\text { Baby } \\
\text { no. }\end{array}$ & $\begin{array}{c}\text { Week } \\
1^{*}\end{array}$ & $\begin{array}{c}\text { Week } \\
4\end{array}$ & $\begin{array}{l}\text { Pre- } \\
\text { solids }\end{array}$ & $\begin{array}{l}\text { After } \\
\text { solids }\end{array}$ & $\stackrel{9}{\text { months }}$ & $\begin{array}{c}12 \\
\text { months }\end{array}$ \\
\hline $\begin{array}{r}8 \\
9 \\
10 \\
11 \\
12 \\
13 \\
14\end{array}$ & $\begin{array}{l}<3 \\
<3 \\
<3 \\
<3 \\
<3 \\
7 \cdot 3 \\
<3\end{array}$ & $\begin{array}{r}<3 \\
<3 \\
<3 \\
\ldots \\
10 \cdot 5 \\
8 \cdot 1 \\
<3\end{array}$ & $\begin{array}{l}<3 \\
<3 \\
8 \cdot 9 \\
8 \cdot 1 \\
\cdots \\
8 \cdot 1 \\
<3\end{array}$ & $\begin{array}{r}<3 \\
<3 \\
10 \cdot 4 \\
8 \cdot 1 \\
8 \cdot 1 \\
8 \cdot 1 \\
<3\end{array}$ & $\begin{array}{r}10 \cdot 1 \\
<3 \\
10 \cdot 3 \\
9 \cdot 2 \\
9 \cdot 3 \\
9 \cdot 2 \\
9 \cdot 5\end{array}$ & $\begin{array}{r}11 \cdot 9 \\
10 \cdot 9 \\
9 \cdot 3 \\
8 \cdot 9 \\
9 \cdot 1 \\
8 \cdot 9 \\
9 \cdot 1\end{array}$ \\
\hline $\begin{array}{l}\text { Mean } \\
\text { count in } \\
\text { babies colonised }\end{array}$ & * & $9 \cdot 3$ & $8 \cdot 4$ & $8 \cdot 7$ & $9 \cdot 6$ & $9 \cdot 7$ \\
\hline
\end{tabular}

Footnotes as in table III.

Bacteroides spp. The isolation of Bacteroides spp. is shown in table IV. These strict anaerobes were isolated from four breast-fed babies during the first week of life. Although many were present for several consecutive days, persistent colonisation was not achieved because bacteroides were not present in any of the four babies at the age of 1 month. All the breast-fed babies except one (no. 7) were colonised some time after the introduction of solid food. Stable colonisation by Bacteroides spp. often occurred at an earlier stage in the formula-fed group, four individuals being colonised before solid food was given. By 12 months of age all infants in both groups were colonised by Bacteroides spp. with numbers ranging from $10^{8}$ to $10^{11} \mathrm{cfu} / \mathrm{g}$.

Anaerobic cocci. Anaerobic gram-positive cocci of the genera Peptostreptococcus and Peptococcus were isolated from breast-fed and formula-fed babies as shown in table V. These bacteria were present as transient members of the faecal flora in one breast-fed baby during the first week of life and one formula-fed baby at week 4 . With the exception of one baby (no. 5), colonisation in both groups occurred at some time after the introduction of solid food. Anaerobic gram-positive cocci had reached $10^{8}-10^{11} \mathrm{cfu} / \mathrm{g}$ in breast-fed and in formula-fed infants by 12 months of age.

Veillonellae were also isolated from four formula-fed infants before and shortly after solid foods were added to the diet. Concentrations ranged from $10^{6}$ to $10^{9} \mathrm{cfu} / \mathrm{g}$. 
TABLE V

Colonisation of the infant large bowel by anaerobic gram-positive cocci

\begin{tabular}{|c|c|c|c|c|c|c|}
\hline \multirow{2}{*}{$\begin{array}{l}\text { Baby } \\
\text { no. }\end{array}$} & \multicolumn{6}{|c|}{ Viable count ( $\log _{10} \mathrm{cfu} / \mathrm{g}$ wet faeces) in breast-fed infants } \\
\hline & $\begin{array}{c}\text { Week } \\
1^{*}\end{array}$ & $\begin{array}{c}\text { Week } \\
4\end{array}$ & $\begin{array}{c}\text { Pre- } \\
\text { weaning }\end{array}$ & $\begin{array}{c}\text { Early } \\
\text { weaning }\end{array}$ & $\begin{array}{c}\text { Late } \\
\text { weaning }\end{array}$ & $\begin{array}{c}12 \\
\text { months }\end{array}$ \\
\hline $\begin{array}{l}1 \\
2 . \\
3 \\
4 \\
5 \\
6 \\
7\end{array}$ & $\begin{array}{l}<7 \\
10 \cdot 2-11 \cdot 2 \\
<7 \\
<7 \\
<7 \\
<7 \\
<7\end{array}$ & $\begin{array}{l}<7 \\
<7 \\
<7 \\
<7 \\
\ldots 7 \\
<7 \\
<7\end{array}$ & $\begin{array}{r}<7 \\
<7 \\
<7 \\
<7 \\
10 \cdot 1 \\
<7 \\
<7\end{array}$ & $\begin{array}{l}<7 \\
<7 \\
<7 \\
9 \cdot 2 \\
<7 \\
<7 \\
<7\end{array}$ & $\begin{array}{r}<7 \\
7 \cdot 1 \\
<7 \\
\text { NA } \\
9 \cdot 3 \\
8 \cdot 1 \\
\text { NA }\end{array}$ & $\begin{array}{r}10 \cdot 4 \\
10 \cdot 2 \\
9 \cdot 1 \\
10 \cdot 1 \\
<7 \\
10 \cdot 5 \\
10 \cdot 1\end{array}$ \\
\hline $\begin{array}{l}\text { Mean } \\
\text { count in } \\
\text { babies colonised }\end{array}$ & * & $\cdots$ & $\cdots$ & $\cdots$ & $8 \cdot 2$ & $10 \cdot 1$ \\
\hline \multirow{2}{*}{$\begin{array}{l}\text { Baby } \\
\text { no. }\end{array}$} & \multicolumn{6}{|c|}{ Viable count ( $\log _{10} \mathrm{cfu} / \mathrm{g}$ wet faeces) in formula-fed infants } \\
\hline & $\begin{array}{c}\text { Week } \\
1^{*}\end{array}$ & $\begin{array}{c}\text { Week } \\
4\end{array}$ & $\begin{array}{l}\text { Pre- } \\
\text { solids }\end{array}$ & $\begin{array}{l}\text { After } \\
\text { solids }\end{array}$ & $\begin{array}{c}9 \\
\text { months }\end{array}$ & $\begin{array}{c}12 \\
\text { months }\end{array}$ \\
\hline $\begin{array}{r}8 \\
9 \\
10 \\
11 \\
12 \\
13 \\
14\end{array}$ & $\begin{array}{l}<7 \\
<7 \\
<7 \\
<7 \\
<7 \\
<7 \\
<7\end{array}$ & $\begin{aligned}<7 \\
<7 \\
<7 \\
\quad \cdots \\
11 \cdot 1 \\
<7 \\
<7\end{aligned}$ & $\begin{array}{r}<7 \\
<7 \\
<7 \\
<7 \\
\quad \dddot{8} \\
<7 \\
<7\end{array}$ & $\begin{aligned}< & 7 \\
& 8 \cdot 9 \\
< & 7 \\
< & 7 \\
< & 7 \\
& 9 \cdot 1 \\
< & 7\end{aligned}$ & $\begin{array}{c}10 \cdot 1 \\
9 \cdot 7 \\
10 \cdot 1 \\
<7 \\
<7 \\
<7 \\
10 \cdot 1\end{array}$ & $\begin{array}{c}11 \cdot 5 \\
11 \cdot 1 \\
8 \cdot 8 \\
<7 \\
<7 \\
9 \cdot 1 \\
9 \cdot 2\end{array}$ \\
\hline $\begin{array}{l}\text { Mean } \\
\text { count in } \\
\text { babies colonised }\end{array}$ & $*$ & $\ldots$ & $\ldots$ & $9 \cdot 1$ & $10 \cdot 1$ & 9.9 \\
\hline
\end{tabular}

Footnotes as in table III.

These organisms did not seem able to persist as major components of the bacterial faecal flora when other anaerobic groups had become established.

Clostridia. Spore counts of clostridia, obtained by the heat-shock technique, are shown in table VI. Clostridia were isolated from six breast-fed infants during the first week of life but from none during the period lasting from week 4 until the introduction of solid food. All breast-fed infants were colonised during the weaning period. Clostridia were isolated from four formula-fed infants during week 1 and permanent colonisation occurred earlier in this group, six babies being colonised before solids were given. By 12 months all infants were colonised by clostridia in numbers ranging from $10^{3}$ to $10^{6}$ spores/g of faeces.

Although heat shocking is the best method available for the selective isolation of clostridia, it must be remembered that spore counts are not accurate estimates of total numbers of clostridia. They may be used, however, as a guide to the relative numbers of clostridia in breast-fed and formula-fed infants.

\section{Facultative anaerobes}

The results for the culture of the facultative anaerobic bacteria are shown in tables VII and VIII. 
TABLE VI

Colonisation of the infant large bowel by clostridia

\begin{tabular}{|c|c|c|c|c|c|c|}
\hline \multirow[b]{2}{*}{$\begin{array}{l}\text { Baby } \\
\text { no. }\end{array}$} & \multicolumn{6}{|c|}{ Spore count ( $\log _{10} / \mathrm{g}$ wet faeces) in breast-fed infants } \\
\hline & $\begin{array}{c}\text { Week } \\
1^{*}\end{array}$ & $\begin{array}{c}\text { Week } \\
4\end{array}$ & $\begin{array}{c}\text { Pre- } \\
\text { weaning }\end{array}$ & $\begin{array}{c}\text { Early } \\
\text { weaning }\end{array}$ & $\begin{array}{c}\text { Late } \\
\text { weaning }\end{array}$ & $\begin{array}{c}12 \\
\text { month }\end{array}$ \\
\hline $\begin{array}{l}1 \\
2 \\
3 \\
4 \\
5 \\
6 \\
7\end{array}$ & $\begin{array}{l}<3 \\
3 \cdot 4-6 \cdot 2 \\
8 \cdot 5 \\
5 \cdot 4 \\
4 \cdot 7 \\
3 \cdot 3-4 \cdot 1 \\
3 \cdot 4-6 \cdot 8\end{array}$ & $\begin{array}{l}<3 \\
<3 \\
<3 \\
<3 \\
\ldots \\
<3 \\
<3\end{array}$ & $\begin{array}{l}<3 \\
<3 \\
<3 \\
<3 \\
<3 \\
<3 \\
<3\end{array}$ & $\begin{array}{l}<3 \\
<3 \\
<3 \\
5 \cdot 7 \\
5 \cdot 3 \\
<3 \\
\quad 4 \cdot 7\end{array}$ & $\begin{array}{l}5 \cdot 2 \\
5 \cdot 5 \\
5 \cdot 5 \\
\text { NA } \\
4 \cdot 2 \\
5 \cdot 2 \\
\text { NA }\end{array}$ & $\begin{array}{l}4 \cdot 3 \\
5 \cdot 2 \\
5 \cdot 2 \\
5 \cdot 8 \\
5 \cdot 5 \\
4 \cdot 6 \\
6 \cdot 1\end{array}$ \\
\hline \multirow[t]{2}{*}{$\begin{array}{l}\text { Mean } \\
\text { count in } \\
\text { babies colonised }\end{array}$} & * & $\ldots$ & $\ldots$ & $5 \cdot 2$ & $5 \cdot 1$ & $5 \cdot 2$ \\
\hline & \multicolumn{6}{|c|}{ Spore count $\left(\log _{10} / \mathrm{g}\right.$ wet faeces) in formula-fed infants } \\
\hline $\begin{array}{l}\text { Baby } \\
\text { no. }\end{array}$ & $\begin{array}{c}\text { Week } \\
1^{*}\end{array}$ & $\begin{array}{c}\text { Week } \\
4\end{array}$ & $\begin{array}{l}\text { Pre- } \\
\text { solids }\end{array}$ & $\begin{array}{l}\text { After } \\
\text { solids }\end{array}$ & $\begin{array}{c}9 \\
\text { months }\end{array}$ & $\begin{array}{c}12 \\
\text { months }\end{array}$ \\
\hline $\begin{array}{r}8 \\
9 \\
10 \\
11 \\
12 \\
13 \\
14\end{array}$ & $\begin{array}{l}<3 \\
<3 \\
<3 \\
5 \cdot 1 \\
5 \cdot 2 \\
3 \cdot 2-5 \cdot 1 \\
5 \cdot 8\end{array}$ & $\begin{aligned} & 7 \cdot 1 \\
&<3 \\
&<3 \\
& \ldots \\
& 5 \cdot 1 \\
& 6 \cdot 2 \\
& 7 \cdot 1\end{aligned}$ & $\begin{array}{c}<3 \\
5 \cdot 3 \\
5 \cdot 1 \\
4 \cdot 3 \\
5.2 \\
6 \cdot 6\end{array}$ & $\begin{array}{l}<3 \\
5 \cdot 1 \\
4 \cdot 1 \\
4 \cdot 1 \\
4 \cdot 1 \\
5 \cdot 9 \\
4 \cdot 6\end{array}$ & $\begin{array}{r}5 \cdot 5 \\
4 \cdot 5 \\
5 \cdot 7 \\
<3 \\
6 \cdot 4 \\
6 \cdot 2 \\
5 \cdot 3\end{array}$ & $\begin{array}{l}4 \cdot 3 \\
3 \cdot 5 \\
5 \cdot 3 \\
4 \cdot 3 \\
5 \cdot 2 \\
5 \cdot 6 \\
6 \cdot 1\end{array}$ \\
\hline $\begin{array}{l}\text { Mean } \\
\text { count in } \\
\text { babies colonised }\end{array}$ & $*$ & 6.4 & $5 \cdot 3$ & $4 \cdot 7$ & $5 \cdot 6$ & $4 \cdot 9$ \\
\hline
\end{tabular}

Footnotes as in table III.

First week. Enterococci were isolated from all babies, and members of the family Enterobacteriaceae from all but three babies during the first week of life. These were the first bacterial groups to colonise the infant intestine and numbers fluctuated widely from $10^{4}$ to $10^{11} \mathrm{cfu} / \mathrm{g}$.

Week 4 to weaning. By week 4, counts of enterobacteria in breast-fed babies had fallen (mean $10^{6.1} \mathrm{cfu} / \mathrm{g}$ ) and they stayed at these levels until solid foods were given. By contrast, counts of enterobacteria in formula-fed infants remained higher throughout this period (mean $10^{9 \cdot 4} \mathrm{cfu} / \mathrm{g}$ ).

The enterococci showed similar trends; in the breast-fed group counts fell (mean $10^{6 \cdot 3} \mathrm{cfu} / \mathrm{g}$ ) while in formula-fed babies counts remained higher (mean $10^{9 \cdot 6} \mathrm{cfu} / \mathrm{g}$ ).

Weaning. The introduction of solid food heralded a sudden increase in numbers of facultative anaerobic bacteria in the faeces of all breast-fed infants. At early weaning, mean counts of enterobacteria and enterococci rose to $10^{8 \cdot 1} \mathrm{cfu} / \mathrm{g}$ and $10^{8.5} \mathrm{cfu} / \mathrm{g}$, respectively. These counts remained high throughout the weaning period.

Numbers of facultative anaerobic bacteria in the faeces of formula-fed infants altered little with the introduction of solid foods. Mean counts for enterobacteria and enterococci were $10^{8.5} \mathrm{cfu} / \mathrm{g}$ and $10^{9.5} \mathrm{cfu} / \mathrm{g}$, respectively.

These results were confirmed by examination of single specimens of faeces from 
TABLE VII

Colonisation of the infant large bowel by enterobacteria

\begin{tabular}{|c|c|c|c|c|c|c|}
\hline \multirow{2}{*}{$\begin{array}{l}\text { Baby } \\
\text { no. }\end{array}$} & \multicolumn{6}{|c|}{ Viable count ( $\log _{10} \mathrm{cfu} / \mathrm{g}$ wet faeces) in breast-fed infants } \\
\hline & $\begin{array}{l}\text { Week } \\
1^{*}\end{array}$ & $\begin{array}{c}\text { Week } \\
4\end{array}$ & $\begin{array}{c}\text { Pre- } \\
\text { weaning }\end{array}$ & $\begin{array}{c}\text { Early } \\
\text { weaning }\end{array}$ & $\begin{array}{c}\text { Late } \\
\text { weaning }\end{array}$ & $\begin{array}{c}12 \\
\text { months }\end{array}$ \\
\hline $\begin{array}{l}1 \\
2 \\
3 \\
4 \\
5 \\
6 \\
7\end{array}$ & $\begin{array}{l}5 \cdot 2-9 \cdot 2 \\
4 \cdot 8-7 \cdot 2 \\
<3 \\
6 \cdot 2-9 \cdot 2 \\
5 \cdot 1-9 \cdot 3 \\
3 \cdot 4-7 \cdot 2 \\
7 \cdot 7-10 \cdot 2\end{array}$ & $\begin{array}{l}3 \cdot 3 \\
7 \cdot 1 \\
6 \cdot 7 \\
4 \cdot 3 \\
\dddot{3} \\
8 \cdot 3 \\
6 \cdot 5\end{array}$ & $\begin{array}{l}4 \cdot 3 \\
6 \cdot 2 \\
6 \cdot 1 \\
4 \cdot 1 \\
6 \cdot 4 \\
5 \cdot 1 \\
6 \cdot 7\end{array}$ & $\begin{array}{l}7 \cdot 3 \\
8 \cdot 6 \\
7 \cdot 2 \\
8 \cdot 7 \\
8 \cdot 5 \\
9 \cdot 1 \\
7 \cdot 4\end{array}$ & $\begin{array}{l}9 \cdot 3 \\
7 \cdot 9 \\
8 \cdot 5 \\
\text { NA } \\
9 \cdot 3 \\
8 \cdot 2 \\
\text { NA }\end{array}$ & $\begin{array}{l}6 \cdot 1 \\
6 \cdot 2 \\
8 \cdot 9 \\
8 \cdot 1 \\
7 \cdot 8 \\
8 \cdot 1 \\
3 \cdot 5\end{array}$ \\
\hline $\begin{array}{l}\text { Mean } \\
\text { count of } \\
\text { babies colonised }\end{array}$ & $*$ & $6 \cdot 1$ & 5.5 & 8.1 & 8.6 & 6.9 \\
\hline \multirow{2}{*}{$\begin{array}{l}\text { Baby } \\
\text { no. }\end{array}$} & \multicolumn{6}{|c|}{ Viable count ( $\log _{10} \mathrm{cfu} / \mathrm{g}$ wet faeces) in formula-fed infants } \\
\hline & $\begin{array}{c}\text { Week } \\
1^{*}\end{array}$ & $\begin{array}{c}\text { Week } \\
4\end{array}$ & $\begin{array}{l}\text { Pre- } \\
\text { solids }\end{array}$ & $\begin{array}{l}\text { After } \\
\text { solids }\end{array}$ & $\begin{array}{c}9 \\
\text { months }\end{array}$ & $\begin{array}{c}12 \\
\text { months }\end{array}$ \\
\hline $\begin{array}{r}8 \\
9 \\
10 \\
11 \\
12 \\
13 \\
14\end{array}$ & $\begin{array}{c}10 \cdot 3-10 \cdot 5 \\
5 \cdot 2-6 \cdot 7 \\
10 \cdot 5-11 \cdot 1 \\
7 \cdot 1-10 \cdot 3 \\
<3 \\
8 \cdot 5-10 \cdot 5 \\
8 \cdot 3\end{array}$ & $\begin{array}{c}10 \cdot 2 \\
9 \cdot 1 \\
10 \cdot 2 \\
\ldots \\
8 \cdot 6 \\
9 \cdot 1 \\
9 \cdot 2\end{array}$ & $\begin{array}{l}7 \cdot 4 \\
7 \cdot 5 \\
9 \cdot 2 \\
8 \cdot 1\end{array}$ & $\begin{array}{l}8 \cdot 7 \\
7 \cdot 9 \\
9 \cdot 3 \\
9 \cdot 4 \\
7 \cdot 1 \\
8 \cdot 6 \\
8 \cdot 3\end{array}$ & $\begin{array}{l}8 \cdot 1 \\
6 \cdot 8 \\
8 \cdot 5 \\
9 \cdot 1 \\
7 \cdot 2 \\
9 \cdot 1 \\
9 \cdot 1\end{array}$ & $\begin{array}{l}9 \cdot 2 \\
6 \cdot 2 \\
8 \cdot 4 \\
6 \cdot 5 \\
7 \cdot 1 \\
7 \cdot 8 \\
8 \cdot 3\end{array}$ \\
\hline $\begin{array}{l}\text { Mean } \\
\text { count of } \\
\text { babies colonised }\end{array}$ & $*$ & $9 \cdot 4$ & $8 \cdot 3$ & 8.5 & $8 \cdot 3$ & 7.6 \\
\hline
\end{tabular}

Footnotes as in table III.

another 20 nine-month-old infants, 10 of whom were receiving a mixed diet of breast milk and solid food, and 10 who had been formula-fed since birth. The results are summarised in table IX.

Counts of enterobacteria and enterococci in breast-fed and in formula-fed 9-month-old infants were significantly higher than corresponding counts in adults (table IX). Furthermore, there was no significant difference in counts of enterobacteria in breast-fed compared with formula-fed infants, while counts of enterococci were significantly higher in the breast-fed group than in the formula-fed group (in all tests of significance, by Student's $t$ test, $\mathrm{p}<0.05$ ).

Twelve months. Counts of faecal enterobacteria had fallen in four breast-fed and two formula-fed infants by 12 months of age. In addition, another three breast-fed and two formula-fed infants who were followed up beyond 12 months also showed decreases in faecal enterobacteria before reaching 18 months of age. Counts of enterococci in both groups of infants also fell to within the adult range as the babies entered the second year of life.

\section{Other genera}

Lactobacilli were isolated from four breast-fed and three bottle-fed infants in 
TABLE VIII

Colonisation of the infant large bowel by enterococci

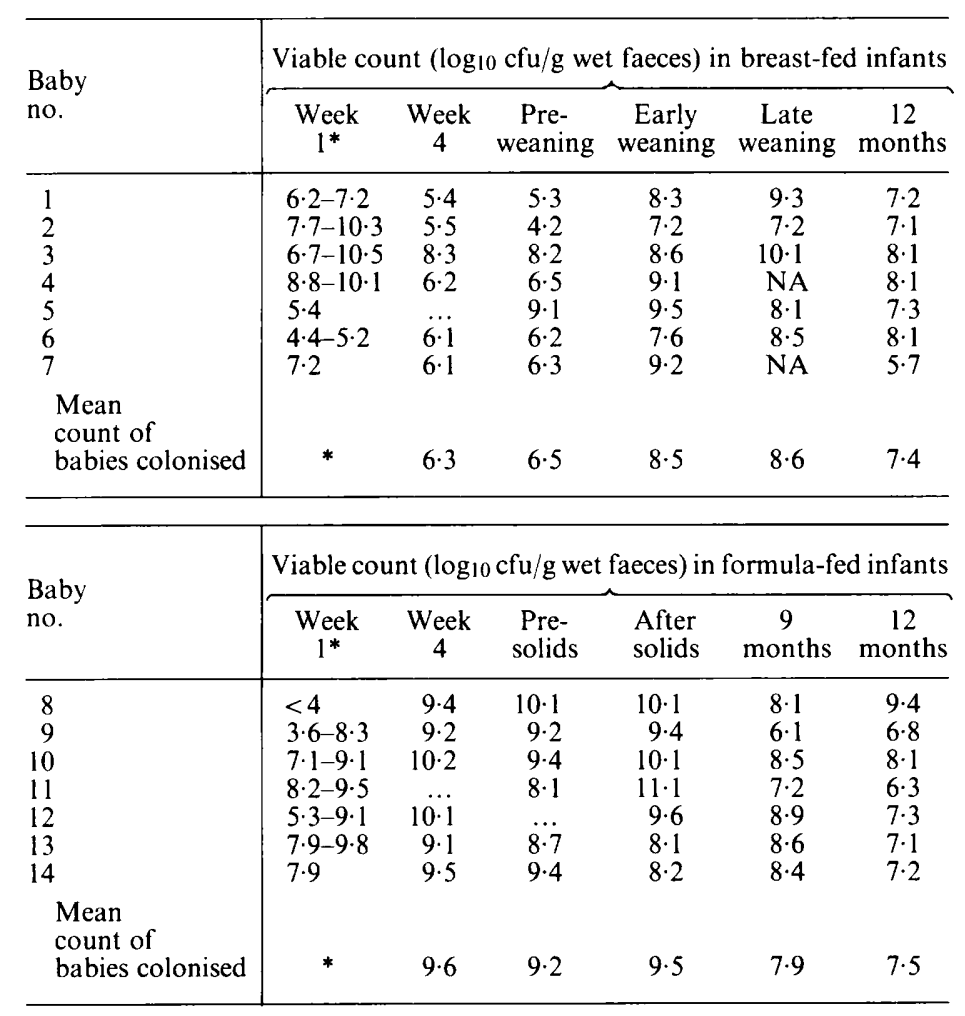

Footnotes as in table III.

counts ranging from $10^{5}$ to $10^{10} \mathrm{cfu} / \mathrm{g}$. Isolations were not continuous for any one baby, however, lactobacilli being present for $2-4$ months and the disappearing. This suggests that lactobacilli are unable to form stable populations in the infant.

Eubacteria colonised four breast-fed and two bottle-fed infants between 9 and 12 months of age, reaching counts of $10^{9}-10^{10} \mathrm{cfu} / \mathrm{g}$.

Staphylococcus aureus was cultured from baby no. 2 during weeks 4-11, and a coagulase-negative staphylococcus from baby no. 12 in the first week and from baby 6 for the first 11 weeks of life.

\section{TABLE IX}

Viable counts of facultative anaerobes in the large bowel of adults and 9-month-old infants

\begin{tabular}{|c|c|c|c|}
\hline \multirow{2}{*}{$\begin{array}{l}\text { Group of } \\
\text { organisms }\end{array}$} & \multicolumn{3}{|c|}{$\begin{array}{l}\text { Mean viable count }\left(\log _{10} \mathrm{cfu} / \mathrm{g} \text { wet }\right. \\
\text { faeces } \pm S D) \text { in }\end{array}$} \\
\hline & 20 adults & $\begin{array}{l}10 \text { formula- } \\
\text { fed infants }\end{array}$ & $\begin{array}{l}10 \text { breast- } \\
\text { fed infants }\end{array}$ \\
\hline \multirow{3}{*}{$\begin{array}{l}\text { Enterobacteria } \\
\text { Enterococci } \\
\text { All facultative } \\
\text { anaerobes }\end{array}$} & $6 \cdot 5 \pm 1 \cdot 2^{*}$ & $7 \cdot 7 \pm 0.9$ & $8 \cdot 1 \pm 0.9$ \\
\hline & $6 \cdot 3 \pm 1 \cdot 3^{*}$ & $7 \cdot 6 \pm 1 \cdot 0$ & $8.8 \pm 0.9$ \\
\hline & $6 \cdot 9 \pm 0.5^{*}$ & $8 \cdot 4 \pm 0 \cdot 9$ & $8.7 \pm 0.9$ \\
\hline
\end{tabular}

* Significantly different from infant values $(p<0 \cdot 05)$. 


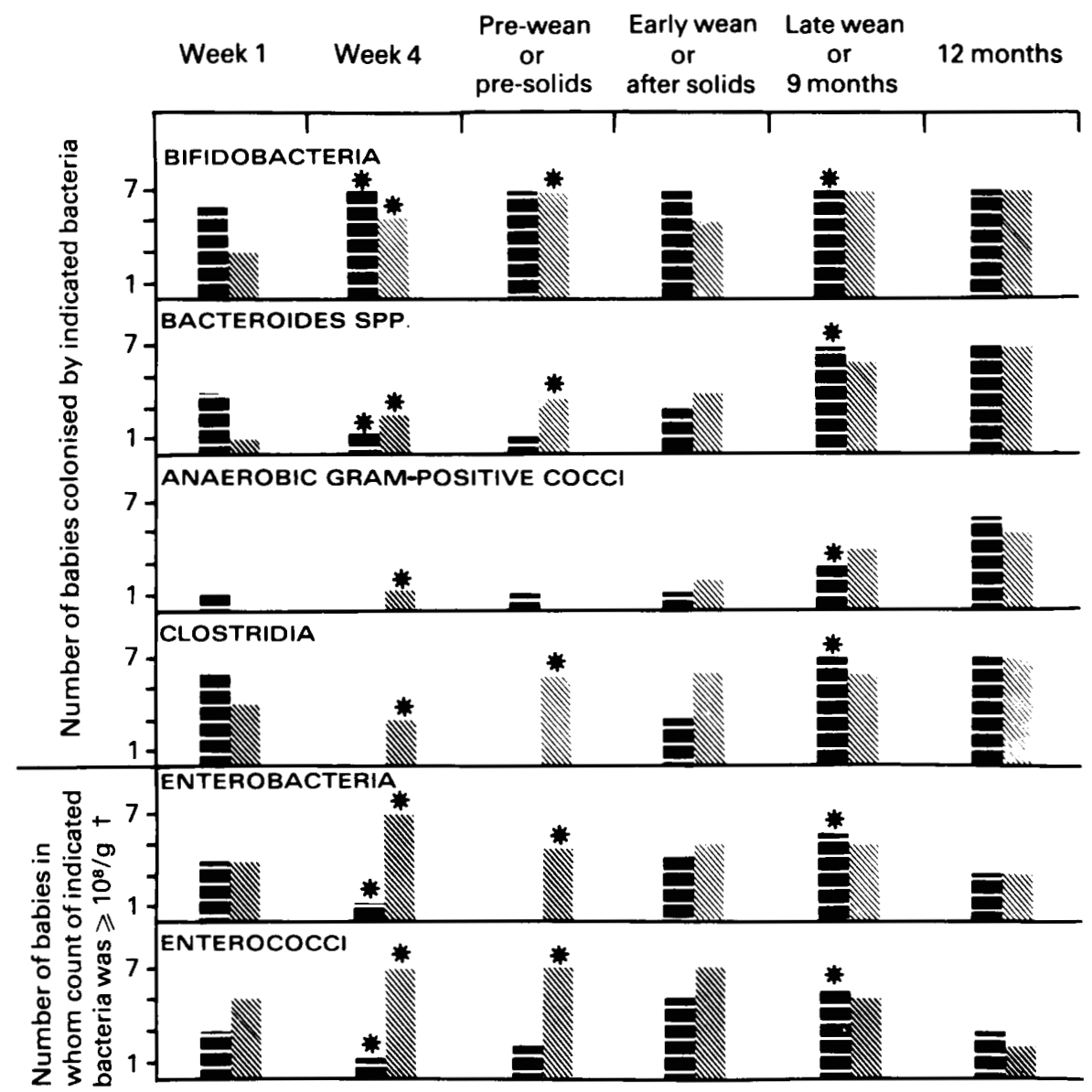

Figure 1-The succession of bacterial populations in the large bowel of breast-fed $(\boldsymbol{C})$ and formula-fed (N) infants.

* When fewer than seven babies were examined the results have been adjusted to a fraction of seven. $\dagger$ Counts of facultative anaerobic bacteria $\geqslant 10^{8} / \mathrm{g}$ faeces are raised in comparison to counts in normal adults.

\section{The succession of bacterial populations}

The succession of bacteria in the large bowel of breast-fed and formula-fed infants is summarised in figure 1.

\section{Discussion}

This is the first long-term prospective study of the microbial ecology of the large bowel of healthy breast-fed and formula-fed infants living in an industrialised community. Apart from one report from rural Guatemala (Mata and Urrutia, 1971), other investigations have concerned infants of different ages, and in some cases receiving different diets (Mitsuoka and Hayakawa, 1973; Ellis-Pegler, Crabtree and Lambert, 1975; Bullen and Tearle, 1976; Hewitt and Rigby, 1976; Albert et al., 1978; Leclerc and Moriamez, 1980). 
As in most studies of the human intestinal microflora, faecal bacterial populations were assumed to be representative of the flora of the lumen of the colon. This assumption has been verified by other authors (Hill and Drasar, 1975; Moore, Cato and Holdeman, 1978).

The number of microbial species in the human intestine is estimated to be more than 400 (Moore et al., 1978). Lack of suitable selective culture media makes it impossible to count many of these organisms; Therefore studies on the development of the intestinal flora can feasibly quantitate only the dominant groups of bacteria or those than can be readily selected. The time and expenditure required for the culture and identification of strict anaerobes also limits the number of isolated colonies that can be identified. Nevertheless, the numerically dominant bacteria probably contribute most to homeostasis in the intestine.

\section{The microbial ecology of the infant large bowel}

Microbial colonisation of the infant large bowel is a complex process lasting throughout the first year of life. Distinct patterns of colonisation can be described although it must be remembered that some degree of individual variation occurs, e.g., staphylococci were isolated consistently from some babies but not from others; one breast-fed baby was colonised by a species of Bacteroides at 4 weeks of age while other infants in the group were not colonised by this organism until weaning was initiated.

In the first week the gastro-intestinal tract of the neonate is seeded with a wide variety of organisms from the birth canal and the baby's surroundings. Organisms best suited to the intestinal environment become established by a process of natural selection. A diet of breast milk creates an environment favouring the development of a simple flora of bifidobacteria and few other anaerobes and small numbers of facultatively anaerobic bacteria. A formula diet also allows bifidobacteria to reach high population densities, equal to those occurring in the climax community in the large bowel of adults, while permitting Bacteroides spp., clostridia and anaerobic streptococci to colonise more frequently, and facultative anaerobic bacteria to reach higher levels.

The introduction of solid food to the breast-fed infant causes a major perturbation in the gut ecosystem, with a rapid rise in the number of enterobacteria and enterococci, followed by progressive colonisation by Bacteroides spp., clostridia and anaerobic streptococci. The addition of solid food to the diet of the formula-fed infant does not have such an impact on the gastro-intestinal flora. Facultative anaerobes remain numerous while colonisation with anaerobes other than bifidobacteria continues. As the amount of solid food in the diet increases, the faecal bacterial flora of breast-fed and of formula-fed infants approaches that of adults.

Other authors consider the ratio of anaerobes to aerobes to be a useful index of intestinal populations (Ellis-Pegler et al., 1975; Albert et al., 1978 and Ellis-Pegler, Higgs and Lambert, 1979). Analysis of our data showed that the ratio of anaerobes to aerobes in breast-fed babies exceeded that in formula-fed babies during the period before solid foods were given (approximately 10:1 and 1000:1 respectively). However, after solids were introduced, ratios in both groups were similar, averaging about 50:1 at 9 months. This change in the breast-fed group was due to the increase in counts of aerobes. By 12 months, ratios in both groups had risen to over 100:1. 
The differences between the faecal bacterial flora of infants who are exclusively breast-fed and those receiving formula has long been a subject of great interest. It was originally considered that the "bifidus flora" of breast-fed infants directly inhibited the growth of coliforms in the large bowel. The present study, in agreement with those of other authors (Hewitt and Rigby, 1976; Mitsuoka and Kaneuchi, 1977), shows that this is not the case because high counts of bifidobacteria were found to co-exist for many months with high coliform counts in the large bowel of formula-fed infants. A more plausible mechanism of coliform suppression has been elucidated by Bullen and colleagues (Bullen and Tearle, 1976; Bullen, Tearle and Willis, 1976; Bullen, Tearle and

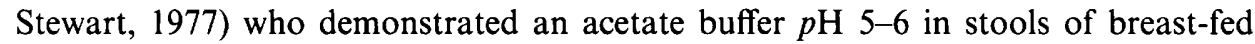
infants that inhibits the growth of gram-negative facultative anaerobes in vitro. In addition, breast-milk factors such as lactoferrin, an iron-binding protein, and secretory IgA may also act to suppress the growth of coliforms in the infant gut (Bullen, Rogers and Leigh, 1972; Bullen, Rogers and Griffiths, 1974).

Interviews with mothers taking part in this survey revealed that exclusively breastfed infants frequently suffered from constipation whereas formula-fed infants did not. This suggests that transit times may be shorter in the latter group and this may contribute to higher coliform levels. Albert et al. (1978) found, in infants suffering from diarrhoea, that a more rapid passage of intestinal contents is associated with increased numbers of faecal enterobacteria.

Colonisation by anaerobes other than bifidobacteria occurred only in the presence of large numbers of facultative anaerobes and one might postulate that these facilitate colonisation by the strict anaerobes by lowering the redox potential of the intestinal lumen. Certainly this phenomenon has been demonstrated experimentally in mice, in which the redox potential of gut contents is considerably higher in germ-free animals than in gnotobiotes colonised by a facultative anaerobe (Celesk, Asano and Wagner, 1976). A highly reduced environment is not so critical for the growth of bifidobacteria (Mitsuoka and Kaneuchi, 1977), isolates from the babies often showing limited growth in aerobic conditions.

The results obtained for the breast-fed infants in this survey are in broad agreement with those reported by Mata and Urrutia (1971). The Guatemalan study, however, described a more gradual increase in enterobacteria throughout the first year, with no decrease around 12 months. This difference is probably due to the practice of prolonged breast-feeding and the insanitary environment in that society.

The low isolation rates for lactobacilli in the Sydney survey are similar to those reported for infants in Guatemala (Mata and Urrutia, 1971), and Britain (Ellis-Pegler et al., 1975), but in contrast to a 75\% isolation rate reported in Japan (Mitsuoka, Hayakawa and Kimura, 1975). This variation could be due to dietary differences between countries.

\section{The influence of changes in the gastrointestinal flora on susceptibility to infection}

Because the normal flora of the gastrointestinal tract is an integral part of the body's nonspecific defence mechanisms, changes in this ecosystem have important implications for the health of the infant. The observation that coliform counts are higher in young formula-fed infants than in exclusively breast-fed infants suggests that the large bowel of formula-fed babies would be more amenable to colonisation by 
gram-negative enteric pathogens than that of their breast-fed counterparts. Several recent studies have shown that the incidence of gastro-intestinal infection is indeed lower in exclusively breast-fed infants. This difference, while more important in underdeveloped countries (James, 1972; Kanaaneh, 1972; Plank and Milanesi, 1973), has also been documented in industrialised societies (Wheatley, 1968; Larsen and Homer, 1978; France, Marmer and Steele, 1980).

Small numbers of coliforms were maintained in the large bowel of breast-fed infants only as long as breast milk was the sole source of nutrition. At weaning, the intestinal milieu is greatly disturbed with rapid changes in bacterial populations. This is in contrast to the homeostasis of the intestinal environment of the formula-fed infants, in whom aerobic populations have been established in large numbers for several months and would be better adapted to their ecological niche and therefore better able to compete against enteric pathogens than the more recently established aerobic organisms in the breast-fed babies. Thus it appears that when solid foods are added to the diet the breast-fed infant could be more susceptible to gastro-intestinal infection than the formula-fed infant. The perturbations occurring in the gut ecosystem of the breast-fed infant at weaning may be an important factor in the pathogenesis of weanling diarrhoea, a common disease of underdeveloped countries where a prolonged and inefficient weaning process is accompanied by malnutrition and intestinal infection (Gordon, 1971). It would be interesting to compare the incidence of intestinal infection occurring soon after solid foods are added to the diet in breast-fed infants with that in formula-fed infants in a westernised society.

An adult type of intestinal bacterial flora is not established in breast-fed or in formula-fed infants until at least 12 months of age. This has been confirmed in another study (Stark and Lee, 1982) on the volatile fatty-acid patterns of human faecal specimens. The acquisition of a range of anaerobic bacteria similar in type and number to those found in the adult presumably increases the infant's resistance to intestinal infection because the human gut anaerobes are considered to have a major role in colonisation resistance against enteric pathogens (van der Waaij, 1979).

\section{The study of the gastrointestinal microflora of infants in pathological states}

This investigation has demonstrated that the composition of the normal intestinal bacterial flora of infants depends on the diet at the time of sampling. Therefore it is very important when studying pathological states that are thought to be related to changes in the intestinal flora, such as neonatal necrotising enterocolitis and infantile diarrhoea, to compare results of faecal culture from sick infants with those from healthy infants receiving the same diet. We hope that the baseline data provided in this paper will be useful in such studies.

\section{REFERENCES}

Albert, M. J., Bhat, P., Rajan, D., Maiya, P. P., Pereira, S. M. and Baker, S. J. 1978. Faecal flora of South Indian infants and young children in health and with acute gastroenteritis. J. med. Microbiol., 11, 137.

Bullen, J. J., RoGers, H. J. AND GrifFITHS, E. 1974. Bacterial iron metabolism in infection and immunity. In Microbial iron metabolism, a comprehensive treatise, edited by J.B. Neilands, Academic Press, New York, p. 517. 
Bullen, J. M., Rogers, H. J. AND LeIGH, L. 1972. Iron-binding proteins in milk and resistance to Escherichia coli infection in infants. Br. med. J., 1, 69.

Bullen, C. L. AND TEARLE, P. V. 1976. Bifidobacteria in the intestinal tract of infants: an in vitro study. J. med. Microbiol., 9, 335 .

Bullen, C. L., Tearle, P. V. and Stewart, M. G. 1977. The effect of "humanised' milks and supplemented breast feeding on the faecal flora of infants. J. med. Microbiol., 10, 403.

Bullen, C. L., Tearle, P. V. AND Willis, A. T. 1976. Bifidobacteria in the intestinal tract of infants: an in vivo study. J. med. Microbiol., 9, 325 .

Celesk, R. A., Asano, T. and Wagner, M. 1976. The size, $\mathrm{pH}$ and redox potential of the cecum in mice associated with various microbial floras. Proc. Soc. exp. Biol. Med., 151, 260.

CROWTHER, J. S. 1971. The transport and storage of faeces for bacteriological examination. $J$. appl. Bact., 34, 477.

Ellis-Pegler, R. B., Crabtree, C. And Lambert, H. P. 1975. The faecal flora of children in the United Kingdom. J. Hyg., Camb., 75, 135.

Ellis-Pegler, R. B., Higgs, R. and Lambert, H. P. 1979. Gastroenteritis in London and Jamaica: a clinical and bacteriological study. J. Hyg., Camb., 82, 101.

Finegold, S. M., Sugihara, P. T. AND SutTer, V. L. 1971. Use of selective media for isolation of anaerobes from humans. In Isolation of anaerobes, Society for Applied Bacteriology Technical Series no. 5, edited by D.A. Shapton and R.G. Board, Academic Press, London, p. 99.

France, G. L., Marmer, D. J. and Steele, R. W. 1980. Breast-feeding and salmonella infection. Am. J. Dis. Child., 134, 147.

Gordon, J. E. 1971. Diarrheal disease of early childhood-worldwide scope of the problem. Ann. N.Y. Acad. Sci., 176, 9.

HewitT, J. H. AND RigBY, J. 1976. Effect of various milk feeds on numbers of Escherichia coli and Bifidobacterium in the stools of new-born infants. J. Hyg., Camb., 77, 129.

Hill, M. J. 1974. Bacteria and the etiology of colonic cancer. Cancer, Philad., 34, 815.

Hill, M. J. AND Drasar, B. S. 1975. The normal colonic bacterial flora. Gut, 16, 318.

Holdeman, L. V. AND MoORE, W. E. C. 1975. Anaerobe laboratory manual, Virginia Polytechnic Institute and State University Anaerobe Laboratory, Blacksburg.

JAMES, J. W. 1972. Longitudinal study of the morbidity of diarrheal and respiratory infections in malnourished children. Am. J. clin. Nutr., 25, 690.

KANAANEH, H. 1972. The relationship of bottle feeding to malnutrition and gastroenteritis in a pre-industrial setting. J. trop. Pediat., 18, 302.

LARSEN, S. A. AND HOMER, D. R. 1978. Relation of breast versus bottle feeding to hospitalization for gastroenteritis in a middleclass United States population. J. Pediat., 92, 417.

LECLERC, H. AND Moriamez, J. C. 1980. Étude quantitative de la flore fécale de l'adulte et du nourrisson alimenté artificiellement. Path. Biol., Paris, 28, 217.

Lee, A., Gordon, J., Lee, C. J. ANd Dubos, R. 1971. The mouse intestinal microflora with emphasis on the strict anaerobes. J. exp. Med., 133, 339.

Mata, L. J. AND URrutia, J. J. 1971. Intestinal colonization of breast-fed children in a rural area of low socioeconomic level. Ann. N.Y. Acad. Sci., 176, 93.

Miles, A. A., MisRa, S. S. AND IRWIN, J. O. 1938. The estimation of the bactericidal power of blood. J. Hyg., Camb., 38, 732.

Mitsuoka, T. and Hayakawa, K. 1972. The faecal flora of man I. Communication: the composition of the faecal flora of different age groups. Zentbl. Bakt. ParasitKde., I. Abt. Orig. A, 223, 333 (in German).

Mitsuoka, T., Hayakawa, K. And Kimura, N. 1975. The faecal flora of man. III. Communication: the composition of lactobacillus flora of different age groups. Zentbl. Bakt. ParasitKde., I. Abt. Orig. A, 232, 499 (in German).

MitsuoKa, T. AND KANEUCHI, C. 1977. Ecology of the bifidobacteria. Am. J. clin. Nutr., 30, 1799.

Moore, W. E. C., Cato, E. P. and Holdeman, L. V. 1978. Some current concepts in intestinal bacteriology. Am. J. clin. Nutr., 31, S33.

Plank, S. J. AND Milanesi, M. L. 1973. Infant feeding and infant mortality in rural Chile. Bull. Wld. Hlth. Org., 48, 203. 
Stark, P. L. AND LEE, A. 1982. The role of volatile fatty acids in the microbial ecology of the large bowel of breast and formula-fed infants (submitted for publication).

VAN DER WAAIJ, D. 1979. The colonization resistance of the digestive tract in man and animals. In Clinical and experimental gnotobiosis, edited by T.M. Fliedner, H. Heit, D. Nethammer and H. Pflieger, Fischer Verlag, Stuttgart. Zentbl. Bakt. ParasitKde, 1 Abt., suppl. 7.

WHEATLEY, D. 1968 . Incidence and treatment of infantile gastro-enteritis in general practice. Archs Dis. Childh., 43, 53.

Willis, A. T. AND HobBs, G. 1959. Some new media for the isolation and identification of clostridia. J. Path. Bact., 77, 511. 